\title{
Resilience in Pre-contact Pacific Northwest Social Ecological Systems
}

\author{
$\underline{\text { Ronald L. Trosper }}^{1}$
}

ABSTRACT. If, like other ecosystems, the variable and dynamic ecosystems of the Pacific Northwest exhibited cycles and unpredictable behavior, particularly when humans were present, the indigenous societies of that region had to have been resilient in order to persist for such a long time. They persisted for two millennia prior to contact with people from the "old world." The Resilience Alliance (2002) proposes that social and ecological resilience requires three abilities: the ability to buffer, the ability to self-organize, and the ability to learn. This paper suggests that the characteristics of the potlatch system among Indians on the Northwest Coast, namely property rights, environmental ethics, rules of earning and holding titles, public accountability, and the reciprocal exchange system, provided all three required abilities. The resulting resilience of these societies confirms the validity of many of the ideas now being discussed as important components in providing successful and sustainable relationships between humans and their ecosystems. That so many separate ideas seem to have been linked together into resilient systems in the Pacific Northwest suggests that social ecological resilience is complicated.

\section{INTRODUCTION}

This paper proposes an extension of previous ecological interpretations of the economic and political institutions of the original peoples of the Pacific Northwest. Since Suttles (1960) proposed that exchange of resources in the potlatch system provided an insurance system to accommodate variability in ecological productivity, anthropologists and others have discussed this possibility (Piddocke 1965, Orans 1977, Johnsen 1986, Trosper 1998, 2002). A reexamination of Northwest Coast institutions in light of new disequilibrium models in ecological theory provides new understanding of Kwakwaka'wakw defense of the "strict law that bids us dance" (Shein and Wheeler 1975).

The new ecological models emphasize the ubiquity of change; to persist in the presence of environmental variability means that a system has features that make it resilient. What persists is the overall state of the system and the types of ecological and social controls that shape the system (Holling and Gunderson 2002). The Resilience Alliance (2002) has proposed that resilient social ecological systems exhibit three characteristics: the ability to buffer disturbance, the ability to self-organize, and the ability to learn. This paper argues that the institutions of the Pacific Northwest coast provided all three characteristics, extending an argument proposed by Wayne Suttles in 1968 (Suttles 1987a), that there may be a list of characteristics that societies need to have in order to cope with particular characteristics of their environment. He posed the problem as coping with "temporary abundance," which is very similar to the topic in this essay; one could say that "to cope" is "to be resilient." A key difference in this paper's approach is that humans are assumed to be part of the ecosystem and a potential source of variability.

The survival of material objects and archeological analysis of them suggest that major features of societies in that region persisted for millennia. In their book reviewing the prehistory of the Northwest Coast, archeologists Ames and Maschner summarize as follows:

Most archeologists working on the coast
feel that the cultures of the Late Pacific
[AD 200/500 to AD 1775] differed little, if
at all, from those observed and recorded
by the first European visitors to the coast.
.. . On the Northwest Coast, with the
overwhelming evidence for cultural
continuity, there is also evidence for
considerable dynamism. (Ames and
Maschner 1999, p. 95)

"Cultural continuity," however, does not mean lack of 
change over time or lack of variation along the coast. In his introduction to Volume 7, "Northwest Coast," of the Handbook of North American Indians, Wayne Suttles (1990a) surveys the broad cultural characteristics of the region, which varied regionally within a broader set of similarities. This paper focuses on the ways these similarities provided the people with possibly helpful rules to govern interaction with the environment of the coast.

In an earlier essay and in the second essay of the Handbook, Suttles describes the region's environmental variability in time and space (Suttles 1987a, 1990b). The region has large rivers, such as the Fraser and Skeena, which present different conditions in the headwaters and near the mouth. Some areas have large amounts of land in the drainages of the tributaries; people relied on those areas for hunting and gathering. Along the coast, some societies could gain considerable resources, including whales, from the sea to supplement the bountiful salmon runs in their much shorter rivers. The ecosystems provided considerable variability, a challenge for the societies' coping abilities.

This tension between continuity and change is evident in the specific surveys of the archeological record for portions of the coast, each of which also supports the above assertion of Ames and Maschner (Fladmark et al. 1990, p. 235; Mitchell 1990, p. 355; Pettigrew 1990, p. 522; Wessen 1990, pp. 420-21). Data on population levels during the pre-contact years show a pattern of increase followed by decrease after $\mathrm{AD}$ 1000 (Ames and Maschner 1999, pp. 54-55); unfortunately the data seem too weak to provide much evidence about population trends.

Because the archeological record can deal only with material records, oral history must be used to determine whether or not activities such as the potlatch ceremonies, selection of titleholders, and other cultural practices existed, along with the evidence of large houses, reliance on salmon, art, and other aspects of the material culture. Although some reject the usefulness of oral tradition, in this case the oral history and the archeological record agree in many respects. Both the Nisga'a and the Gitksan appeal to oral histories of their houses, adaawak, to establish rights in the Nass Watershed (Sterritt et al. 1998). Mills (1994, pp. 72-100) finds a partial match between oral histories and archeological evidence in the Skeena River watershed. Some oral histories that report these cultural practices are available in Hunt (1898-1899),
Nisga'a Tribal Council (1995a), and Golla (2000).

The record of sustainability on the Northwest Coast sets a standard for persistence, such as Costanza and Patten (1995) urge be used for judging sustainability. These societies should be studied carefully for insights that may be useful in today's consideration of the characteristics of resilient social ecological systems.

\section{CHARACTERISTICS OF THE POTLATCH SYSTEM}

This section of the paper addresses each of the three conditions for resilience proposed by the Resilience Alliance: buffering disturbance, self-organization, and learning. Before relating the institutions of the Northwest Coast to the three conditions, a brief introduction to these institutions is necessary. (The paper draws upon Adams 1973, Cove 1982, Donald 1997, McNeary 1994, Newell 1993, Nisga'a Tribal Council 1995a-c, Oberg 1973, Suttles 1987b and 1990c, Walens 1981 and visits with people of the Nisga' a Nation in 1998 and 2000.)

Most know of the great reciprocity system of potlatch ceremonies and feasts that were so prominent on the Northwest Coast. Potlatch ceremonies were highly structured events, in which the distribution of goods followed strict rules and was publicly acknowledged. Although Franz Boas (1966) suggested a potlatch event created status, a more complex analysis has shown that potlatching was a requirement of titleholding and could just as well be seen as a consequence of status (Adams 1973, Mills 1994, Donald 1997). Mauss (1967 [1950], pp. 78-79) describes the potlatch as "the totality of society and its institutions." This paper follows Mauss: potlatch ceremonies organize a system, but the system also includes nature.

Titleholders of houses organized the ceremonies. Northwest Coast societies all consisted of "houses": corporate groups with proprietorship in specific lands and fishing sites, directed by the persons holding offices in the houses. Because these offices each had a title inherited through a kinship system and because no state-level political institutions existed, Donald (1997) has urged that the heads of the houses be called titleholders rather than chiefs. To call them "chiefs" implies existence of state-level institutions, as described in the literature on political evolution (Johnson and Earle 2000). Members of a house were bound together by kinship and had rights to use 
specific lands and fishing sites under the direction of the head titleholder. Houses consisted of lesser titleholders, commoners, and slaves.

Although the house, its titles, and the land it controlled were linked together, the head titleholder of a house would refer to the lands of the house as "my land." The head titleholder was in charge of land management; no one could use the land without permission. Even being present on the land required approval; trespass was a capital offense that would be enforced, usually after a warning. Killing a trespasser obligated the enforcer to invite the members of the trespasser's house to a feast in order to prevent a cycle of killing from occurring.

Of the modern terms to describe property systems (Schlager and Ostrom 1992), "proprietorship" best fits the Northwest Coast. The titleholders of houses were the proprietors of the lands of the house, with the ability to exclude others, manage, harvest, and bequest the lands and resources. Sale was not a possibility; a market in land did not exist. Hence, the houses were not "owners," as the term is commonly used.

Ceremonies occurred for many reasons; important ones were marriages, deaths, and the resulting transfers of titles. After the death of a head titleholder, the successor would organize a major ceremony in order to obtain recognition of the right to inherit the title and to take charge of the lands of a house. Head titleholders of other houses, by accepting the gifts of the host, recognized the host's claim. Such events occurred when a new titleholder raised a totem pole to honor the previous titleholder and recounted the origin story for the house.

\section{Ability to buffer disturbance}

The Pacific Northwest systems provided ways to buffer disturbances both from the ecosystem and from humans. Buffering was provided by interactions among the potlatch system of reciprocal exchange, the rules that made land proprietorship contingent on correct management decisions, the use of potlatch ceremonies for cross-scale negotiations among titleholders, commoners' choices, and belief systems.

Wayne Suttles (1960, 1987a) argues that the reciprocal exchanges of a potlatch system provide a method of social insurance against variation in harvest abundance. Because titleholding families intermarried, the bonds and obligations of kinship could be used to provide a way for people living in different areas to provide aid to people in other areas. This system would work if the property-managing units depended upon different resources, yet were linked through social ties. Such was the case in the different regions of the Pacific Northwest. Ray (1991, pp. 304-305) reports an extreme case, in which the failure of a salmon run caused an entire village to cross over a watershed divide and seek sustenance from others; the assistance obtained had to be repaid at a later date. This type of buffering system had to operate at a relatively large scale, as salmon run failures would occur over an entire river system or tributary to a major river. Regional networks existed in separate parts of the Coast (Suttles 1990a, p. 12).

On a smaller scale, when neighboring houses all harvested from a major river, they had to deal with the interdependence of their harvests. As Trosper (1998) explains, the knowledge that neighbors would share their surplus through the potlatch system provided a solution to the "prisoner's dilemma" of a commonpool resource. Sharing net returns for harvest changes the payoff matrix to make cooperation the correct strategy for rational players; these incentives prevent over-harvesting, thus buffering human impacts on fishery resources.

The rules for maintenance of leadership positions provided another method of buffering human activity. Although titles were inherited, sufficient choice existed within the inheritance process for standards of good leadership to be required. In order to inherit a title and, with the title, control of the resources of a house, a person had organize the house to generate a surplus sufficient to satisfy other titleholders. The others indicated their acceptance of the titleholder by accepting the gifts given in a potlatch feast. If the other titleholders did not accept the new titleholder, they would refuse the gifts.

After titleholders were confirmed in their positions, they remained obligated to host feasts and distribute wealth to other titleholders. At these ceremonies, other titleholders could express their opinions on any issues they wished. In some societies, the host had to listen silently. Mills (1994) explains at length the methods of reaching joint agreement among the Wit'suwit'en; these systems of joint agreement also affected other components of resilience. Although many observers, such as Boas, stressed the role of potlatch ceremonies in affirming status, other observers such as Mills and contemporary members of these societies emphasize 
the governing aspect of the potlatch system (Nisga'a Tribal Council, 1995c; McNeary 1994). When Canada outlawed potlatching between 1885 and 1951, it interfered with the self-government of Northwest Coast peoples (Rose 2000, pp. 21-80).

Titleholders also had to please the members of their houses, who had options regarding which of their kinship ties they would use. Weinstein (1994) points out that this flexibility allowed the commoners to choose to live in the house whose titleholder managed best. If, as a consequence of armed conflict, a head titleholder was captured and held for ransom, his followers (lesser titleholders and commoners) could decide whether or not to buy the titleholder back (Donald 1997).

Among some societies of the area, such as the Nuuchah-nulth and the Kwakwaka'wakw, failure of resources would lead the members of a house to conclude that the titleholder had lost his spiritual ability, and they would kill the titleholder in order to obtain a better leader (Walens 1981). Thus, the leadership position of titleholders was contingent upon good stewardship of the land and upon the ability to give away a surplus generated from the land.

The requirement that titleholders be good stewards of the resources under their control was characteristic of the ethical systems of the region (Turner et al. 2000). Failure to care for the land under his control was evidence that a titleholder was not worthy of his position. Stanley Walens describes an example of the unity of humans and nature in describing Kwakwaka'wakw (Kwakiutl) beliefs:

The Kwakiutl believe that animals and spirits lead lives that are exactly equivalent to those of humans. They live in winter villages, perform dances, wear masks, marry, pray, and perform all other acts that humans perform. . . In fact, since animals are considered to be human beings who have donned the masks and costumes that created their animal forms, people are united with the animals by virtue of the fact that they are all actually human beings. (Walens 1981, p. 23)

Humans and animal souls were both involved in cycles of reincarnation. One purpose of a potlatch was for a titleholder to symbolically allow for cycling of food by giving his wealth to titleholders in related villages. Failure to hold adequate feasts and to distribute wealth would interfere with the reincarnation of salmon and other nonhumans, essential to generate that very wealth (Seguin 1984, Walens 1981).

Given the productivity of the ecosystems in the Pacific Northwest, creation of chiefdoms or other larger state structures was possible and would have been a major disturbance to the system, changing its character. Johnson and Earle (2000, p. 262), in their examination of the evolution of chiefdoms and other large state structures, note the absence of such a development on the Northwest Coast. How might the institutions of the Northwest Coast have discouraged emergence of regional chiefdoms?

One mechanism of emergence would have been for one of the titleholders on a major river to subjugate the others in the valley. A titleholder desiring to establish a "chiefdom" with power over his neighbors would need simultaneously to retain the loyalty of his followers through the productivity of his rule and resist the opposition of other titleholders to his growing control of resources. Upon taking a neighboring titleholder's land, the property system required that other titleholders recognize title by accepting gifts at a feast. A coalition of all other titleholders refusing the gifts would be a first step in their resistance. According to the sacred beliefs, failure to successfully feast and share output would potentially threaten the salmon runs, and thus lead to doubt among the aggrandizing titleholder's followers regarding his long-term success.

The common-pool nature of the salmon resource would also provide leverage to other titleholders. As the expanding titleholder would no longer be part of the system of sharing the surplus, all the titleholders would be vulnerable to the consequences of excessive exploitation. If the aggrandizing titleholder was a downstream titleholder, the upstream titleholders could control spawning. If he was an upstream titleholder, they could harvest entire runs before they reached his territory and thus deprive him of support. The competition caused by conflict among titleholders, by leading to excessive harvest, would simultaneously threaten all of their positions, although the upstart would be more vulnerable because of the inability to give away his wealth. Through use of the controls created by the potlatch system, other titleholders could convince those who desired to increase their share that the ultimate result would be disaster for all. The result is a strong mechanism to prevent the emergence or limit the scope of regional chiefs from among the titleholding class. 


\section{Ability to self-organize}

In order for a system to be resilient, it must be able to reorganize if the buffering mechanisms described in the previous section fail, resulting in major disorganization. A system that can self-organize establishes itself without external guidance or direction. Several sources could provide large disturbances in the Pacific Northwest. The buffering pressures to prevent a titleholder from military conquest of neighboring houses might fail. Conquest might lead one whole population of a watershed to be removed. Another source of disturbance could be technological change, such as acquiring the ability to harvest whales. A third source of disturbance could be great declines in salmon abundance caused by changes in ocean conditions.

In the case of military conquest, the system could be re-established by use of the recognition of proprietorship. The principle of proprietorship was that those in control of houses received recognition of their right to rule when their neighboring titleholders accepted gifts. A new titleholder could persuade his neighboring titleholders to accept his conquest through acceptance of his gifts at a feast. If the neighbors objected to the control, they would refuse to attend a ceremony - a feast and distribution of gifts. As Johnsen (1986) has pointed out, this was a peaceful substitute for violent conflict. It also provided a way for the consequences of violent conflict to be ratified by other titleholders.

Another source of system-changing disturbance could be technological change, such as discovering how to harvest whales. A Nu-chah-nulth oral history that recounts the consequences of learning how to capture whales illustrates the capacity of the house system to reorganize and incorporate change into the pattern of titleholders. Initially, established titleholders (who relied on seals) killed their rivals who had learned how to capture the more lucrative whales. The change in technology affected who would be able to lead the community. The grandchildren of the feuding titleholders, however, resolved the dispute and the community began to harvest whales; all houses changed a portion of their harvest base from seals to whales (Atleo 2001, pp. 89-98).

Externally caused changes in ocean conditions could affect salmon runs, and humans needed to be able to adjust to those conditions. Johnsen (2001) asserts that exclusive control of streams allowed titleholders to control some of the evolutionary forces operating on salmon. Titleholders could affect the timing of runs and the size of the fish with relatively easy actions, given the efficiency of stream barricades that allowed selection of which fish to harvest. Humans thus were a keystone species, supporting monitoring of ecosystem structure through management of salmon and other resources; humans became a force in co-evolution. Copes (2000) has proposed that restoration of this type of stream-specific control could assist in restoring runs to higher levels of productivity. Such controls could be used to adjust for changed ocean conditions. Turner et al. (2000) also describe the ways in which native peoples cared for plants in house territories.

A feature of the ceremonial system was that all exchanges were publicly announced. Counters kept track of the exchanges. This public accountability allowed peers and subjects to monitor the success of their titleholders. Such monitoring contributed to selforganization by providing a way for lesser titleholders and commoners to know how well the head titleholder was managing their lands.

An aspect of self-organization in social ecological systems is the presence of system memory. In addition to providing adequate gifts in a feast, new titleholders also had to demonstrate that they knew the stories of the founding of their houses, and subsequent events. Those in line to become titleholders were expected to be trained for the position, and to demonstrate their knowledge as a condition of inheritance. Thus, when a titleholder died, systems were in place to ensure that a well-trained successor would take over. The oral histories of each of the houses contained memory of earlier events. [I do not know of an analysis of the level and quality of ecological information in the stories; such an analysis would be helpful in supporting this assertion. Atleo (2001) evaluates a Nuchah-nulth myth for its lessons in coping with change in the food base from seals to whales.]

\section{Social learning}

The houses' oral histories provided a basis for training titleholders, and contributed to memory and reorganization after crisis, particularly the death of a valued elder. The house organization also provided a basis for learning. Bruce Johnsen (2001) identifies one of the reasons for such learning: clear proprietorship of a stream, with the runs of salmon. Johnsen proposes that clear control of salmon habitat would allow titleholders to benefit from learning how to manipulate 
the quality of the runs. He further proposes that the simultaneous appearance of the house system and abundant salmon are causally connected; both developed together.

Johnsen's argument addresses individual learning by titleholders. We know that titleholders were regarded as people with special knowledge and spiritual power (Suttles 1960). There was an aspect of secrecy and privately held knowledge underpinning the position of titleholders. Yet, there also had to be a shared system of knowledge, if scientific understanding had developed among them. Knowledge of fish biology and evolutionary responses to management would have been a public good among the titleholding class, much as basic science is a public good today. We know that science and scientific discovery requires public discussion and checking of results.

The system of public reciprocity among titleholders and the intermarriage among titleholding families allowed for shared learning. The ethnographic record seems to be quite sparse when describing the nature of discussions among the titleholding class; there seems to be little direct evidence that joint knowledge development about salmon biology and other characteristics of ecosystem behavior were topics of discussion. If they were, however, the potlatch reciprocity system meant that advances in the management of a neighbor's stream would be shared by all who were linked to that neighbor in the system of exchange.

The system of ethics also supported individual and social learning. The peoples of the Northwest Coast believed that proper behavior by titleholders was a requirement for the return of the salmon each year. They believed in careful husbandry of the resource, and required that leaders show respect for the resources upon which they depended. Salmon had powers of their own, which could be used to the detriment of humans should improper behavior occur. Humans and salmon were seen to be part of the same system; human flesh was salmon flesh, and vice versa. The fearful drama of the hamatsa dance involved the taming of a cannibal, thus controlling dangerous hunger (Walens 1981; Suttles 1991). The natural system was not separate from the human system; both were linked, requiring proper human behavior in order to preserve the entire system. Such a system of thought would mean that the actions of humans had to be studied, and their consequences understood.
Leaders were also encouraged to consider the longterm impacts of their actions, because all believed that they had been leaders in the past, and their spirits would be reincarnated in their line of succession in the future (Mills and Slobodin 1994). Investments in knowledge and salmon management today would be of direct benefit to them in a later life. Such a belief would also support the development and maintenance of knowledge about ecosystems and the ways to preserve and enhance their productivity.

\section{DISCUSSION}

This proposed interpretation of the institutions surrounding the potlatch so extends the "functional" interpretation of Suttles (1960) and Piddocke (1965) that anthropologists who wish to domesticate the "functional dragon" will be very uneasy (Orans 1977). I wish to address these concerns, as I argue it is not just coincidence that the potlatch system existed in the Pacific Northwest and that similar cultures persisted in that area for two millennia.

Simply summarized, the functionalist version of this argument goes as follows, using Orans's terminology. The variable and dynamic ecosystems of the Pacific Northwest, like other ecosystems, exhibit cycles and unpredictable behavior, particularly when humans are present. This "state" creates a "need" for a social ecological system to be resilient in order to persist for a long time. Ecological resilience as defined by the Resilience Alliance exhibits three abilities: to buffer, to self-organize, and to learn. The "traits" of the potlatch system are the property rights ideas, the ethics, and the titleholding rules, and the exchange system that ties the property rights, ethics, and leadership roles together. As explained above, one can give good reasons why these traits would provide the three abilities, and thus fulfill the need.

But good reasons (although abundant) are not enough to satisfy critics of functionalist arguments. That potlatchtype systems existed, with variation, throughout most of the salmon-based economies is also not sufficient, as they occurred in only one region of the globe. I agree and propose two responses: cross-cultural evidence should be brought to bear; and analysis of the problem should show that the good reasons are especially good reasons. They are good reasons because they have been rediscovered by people searching for ways to deal with short-term environmental problems, such as pollution, and by people searching for policies to support long-term sustainable use of ecosystems. 
First, cross-cultural evidence and comparisons are needed in order to establish connections between these traits and resilience of social ecological systems. The institutions and ecosystems of other cultures that have persisted need to be investigated: did similar institutions exist among other cultures dependent on salmon, such as those in Northern Europe? Did similar institutions exist in other persistent cultures in other types of ecosystems that exhibit the properties of cycles and unpredictable behavior? One possibility is that the archeological cultural continuity exhibited on the Canadian Shield for over 3000 years prior to contact, summarized by Wright (1981), can be connected to institutions similar to those of the Northwest Coast. The works of Feit (1978, 1988, 1991), Tanner (1979, 1988), and Berkes (1999) regarding the Cree peoples in Canada, suggest they used similar ideas of proprietorship, ethics, and contingent leadership. Bishop (1998) argues that they had potlatch-like activities prior to contact.

A problem hampering full pursuit of cross-cultural comparisons is that detailed information on cultural content, such as described in this paper, is hard to discover for past cultures. Suttles (1987a, p. 62) suggests that a search for functional equivalents to Northwest Coast institutions may be helpful. Tainter (1988) tackles the difficult task of examining complex societies that persisted and then disappeared; he asserts there is an upper limit to the amount of complexity and associated hierarchy that can survive. The Pacific Northwest societies had regional networks but no higher-level political institutions, suggesting they were well below the upper limit of complexity. McIntosh et al. (2000) have examined methods used by many cultures to cope with long-term climate change. Boehm (1999) explores evolutionary aspects of how humans have acted to limit, but not eliminate, hierarchy. One way to restrain the dominant behavior of some individuals is to insist that they act generously. Based primarily on contemporary data, Fiske (1991) argues that four elementary forms of human relations are combined in different ways in all societies: hierarchy, balanced reciprocity, generalized reciprocity, and proportional division. Johnson and Earle (2000) compare societies with different degrees of complexity in their political structure. Although they include Northwest Coast societies in their comparisons, they do not explain why the political complexity of these societies did not increase over the timeframe examined here. These works suggest that Suttles' recommendation for comparative study of functional equivalents may be possible.
Analysis of comparative data such as those cited above provides a good basis for response to the concerns raised by those worried about the functional dragon. A second response is analytical: all the characteristics of the Pacific Northwest societies have been proposed independently by those seeking ways to address current ecological crises and the need for sustainability. All the following ideas can be found in the current literature: (1) cooperative decision-making, (2) social learning, (3) environmental ethics, (4) contingent proprietorship, (5) balanced reciprocity, and (6) public accountability.

1. Proposals that cooperative decision-making can enhance adaptive ecosystem management hark back to the use of consensus decisionmaking among traditional leaders. Many authors who advocate adaptive ecosystem management also advocate public participation (Committee of Scientists 1998, Shindler and Cheek 1999, Cortner and Moote 1999). They recognize that everyone's actions need to be coordinated, and also that different members of the public have different information about the operation of local systems.

2. The idea of sharing learning and scientific inquiry motivates recommendations to use management to learn; this is consistent with sharing and the ethics of science. What is now called adaptive management (the careful design of human actions, combined with monitoring of the results) stems from the indigenous idea that humans are responsible for their actions in nature. Yet the idea of adaptive ecosystem management is "socially challenged," according to a recent symposium in Conservation Ecology (Johnson 1999). One reason for the challenge, perhaps, is the scarcity of reciprocity in modern exchange systems. Paul David (1998) asserts that, even in the highly competitive environment found in modern corporations that are developing new technology, the scientists involved create "invisible colleges" governed by reciprocity principles in the sharing of new knowledge. One prominent biologist recently said "science is valuable, let's give it away" (Menninger 2001). A disconnect is that modern exchange systems outside of science do not emphasize reciprocity.

3. A third similarity is the area of ethics regarding the relationship of humanity and 
nature. The idea of respect for nature has only recently become somewhat popular, and remains a distinct minority view. People have recognized that acceptance of the idea that humans are part of ecosystems seems to be a crucial step in movement toward acceptance of sustainability as a goal (Latour 1993, Cortner and Moote 1999). Although the principle of reincarnation on the Northwest Coast does not recur in the current literature on environmental ethics, the consequences of the reincarnation beliefs are ideas that are similar to the new environmental ethics. In particular, leaders are encouraged to look far to the future when considering the consequences of their actions. Callicott (1994) surveys the relationship between many concepts of the sacred and environmental ethics.

4. Bioregionalism urges that people become tied to where they live. The literature on management of common property resources emphasizes the importance of the power to exclude combined with self-governance and public accountability (Ostrom 2001). On the Northwest Coast, people were tied to their landbase. Those who controlled the land were proprietors, not owners, because they could not sell their land. Transfer of land occurred only through the rules of inheritance, which emphasized eligibility through kinship and the training of youth. Holding of titles was contingent on proper management, as judged both by productivity of the land and by stewardship of that productivity.

To the virtues of proprietorship, should be added the virtues of contingent proprietorship. Anglo-American property law allows society to limit public nuisances and the state to exercise police powers; these ideas serve as limits on absolute ownership and provide a way to address environmental concerns (Sax 1964, 1971; Merrill 1998). These principles, however, have been given narrow scope by courts for over 100 years (MacEvoy 1998). In the United States, some landowners wish to have unchecked powers over their lands, uninhibited by principles such as stewardship. In 2002, however, the U. S. Supreme Court upheld the use of the police power to regulate land use in order to protect Lake Tahoe (Tahoe-Sierra Preservation Council, Inc. vs.
Tahoe Regional Planning Agency, decided April 23, 2002), although the case dealt with the narrow issue of a temporary restraint on development. Recent innovations allowing conservation easements permit voluntary adoption of contingent ownership based on a promise to apply land stewardship.

5. Only recently have economists recognized the importance of reciprocity in exchange among people who share use of common-pool and public goods. Varian (1994) proposes that if firms experiencing externalities specify penalty rates for each other, an official can arrange that the resulting side payments lead the firms to choose efficient levels of production; Varian presents a reciprocity model. Chichilnisky et al. (2000) demonstrate that an optimal solution to the problem of global warming involves transfers of wealth among all countries, another reciprocity model. Although these economists do not label their proposals "reciprocity," French economist Serge-Christophe Kolm (2000) has explicitly recognized the connection. Sharing also encourages investment in public aspects of scientific knowledge through adaptive management.

6. The sharing of net returns, which the potlatch accomplished, is only part of the incentive to cooperate, however. Public revelation of the shared returns provides additional accountability for good management. In the United States, laws requiring ecosystem assessment (such as the National Environmental Policy Act) and the Freedom of Information Act have forced revelation of facts about ecosystem use and implicit subsidies offered by governments. These types of revelations improve management decisions.

The growing literature on the management of common-pool resources examines a problem contained within the general problem of resilience: management of the components of an ecosystem that produces homogenous units. The eight design principles Ostrom (1990, 2001) identifies for long-enduring institutions that manage such common-pool resources are also characteristics found in the systems of the Northwest Coast.

In summary, all of the characteristics of the resilient social ecological systems of the Northwest Coast of 
North America have been proposed in various contexts as components that contribute to sustainable resource management. That the components can fit together to provide resilience is suggested by the persistence these societies demonstrated before their political and economic systems were disrupted two centuries ago. Comparisons of the Northwest Coast to other examples of resilience should help clarify which of these characteristics must be present, and which can be present in other forms.

Responses to this article can be read online at: http://www.consecol.org/vol7/iss3/art6/responses/index.html

\section{Acknowledgments:}

This paper draws upon research supported by a Pew Fellowship for Conservation and the Environment. Discussions in the summer of 2001 with members of the Resilience Alliance were very helpful regarding resilience, as was a discussion with the Board of Wilp Wilxo'oskwhl Nisga'a of the Nisga'a Lisims Nation regarding my understanding of their traditions. Reviewers and the subject editor for this journal made many useful suggestions that improved the paper. Remaining errors are the author's responsibility.

\section{LITERATURE CITED}

Adams, J. W. 1973. The Gitksan potlatch: population flux, resource ownership, and reciprocity. Holt, Rinehart \& Winston of Canada, Toronto and Montreal.

Ames, K. M., and H. D. G. Maschner. 1999. Peoples of the Northwest Coast: their archeology and prehistory. Thames and Hudson, London, UK.

Atleo, M. T. 2001. Learning models in the Umeek narratives: identifying an educational framework through storywork with First Nations elders. Dissertation. University of British Columbia, Vancouver, British Columbia, Canada.

Berkes, F. 1999. Sacred ecology: traditional ecological knowledge and resource management. Taylor \& Francis, Philadelphia, Pennsylvania, USA.

Bishop, C. A. 1998. The politics of property among Northern Algonquians. Pages 247-267 in R. C. Hunt and A. Gilman, editors, Property in economic context. University Press of America, Lanham, Massachusetts, USA.

Boas, F. 1966. Kwakiutl ethnography. (H. Codere, editor.) University of Chicago Press, Chicago, Illinois, USA.
Boehm, C. 1999. Hierarchy in the forest: the evolution of egalitarian behavior. Harvard University Press, Cambridge, Massachussetts, USA.

Callicott, J. B. 1994. Earth's insights: a multicultural survey of ecological ethics from the Mediterranean Basin to the Australian Outback. University of California Press, Berkeley, California, USA.

Chichilnisky, G., G. Heal, and D. Starrett. 2000. Equity and efficiency in environmental markets: global trade in carbon dioxide emissions. Pages 47-67 in G. Chichilnisky and G. Heal, editors. Environmental markets: equity and efficiency. Columbia University Press, New York, New York, USA.

Committee of Scientists. 1999. Sustaining the people's lands: recommendations for stewardship of the national forests and grasslands into the next century. United States Department of Agriculture, Forest Service,Washington, D. C., USA. [Online] URL: http://www.fs.fed.us/forum/nepa/rule/cosreport.shtml.

Copes, P. 2000. Aboriginal fishing rights and salmon management in British Columbia: matching historical justice with the public interest. Pages 75-91 in E. E. Knudsen, C. R. Steward, D. D. MacDonald, J. E. Williams, and D. W. Reiser, editors. Sustainable fisheries management: Pacific salmon. CRC Press LLC, Boca Raton, Florida, USA.

Cortner, H. J., and M. A. Moote. 1999. The politics of ecosystem management. Island Press, Washington, D. C., USA.

Costanza, R., and B. C. Patten. 1995. Defining and predicting sustainability. Ecological Economics 15(3):193196.

Cove, J. J. 1982. The Gitksan traditional concept of land ownership. Anthropologica 24(1):3-18.

David, P. A. 1998. Communication norms and the collective cognitive performance of "invisible colleges." Pages 115-163 in G. B. Navaretti, P. Dasgupta, K.-G. Maler, and D. Siniscalco, editors. Creation and transfer of knowledge: institutions and incentives. Springer-Verlag, Berlin, Germany.

Donald, L. 1997. Aboriginal slavery on the northwest coast of North America. University of California Press, Berkeley, California, USA.

Feit H. A. 1978. Waswanipi realities and adaptions: resource management and cognitive structure. Dissertation, University of Michigan, Ann Arbor, Michigan, USA.

Feit H. A. 1988. Waswanipi Cree management of land and wildlife: Cree ethno-ecology revisited. Pages 75-91 in B. A. Cox, editor. Native people, native lands: Canadian Indian, Inuit and Metis. Carleton University Press, Ottawa, Ontario, 
Canada.

Feit H. A. 1991. The construction of Algonquian hunting territories: private property as moral lesson, policy advocacy, and ethnographic error. Pages 109-134 in G. W. Stocking, Jr., editor. Colonial situations: essays on the contextualization of ethnographic knowledge. History of Anthropology: 7. University of Wisconsin Press, Madison.

Fiske, A. P. 1991. Structures of social life: the four elementary forms of human relations. The Free Press, New York, New York, USA.

Fladmark, K. R., K. M. Ames, and P. D. Sutherland. 1990. Prehistory of the northern coast of British Columbia. Pages 229-239 in W. Suttles, editor. Northwest coast. U. S. Government Printing Office, Washington, D. C. (W. C. Sturtevant, general editor, Handbook of North American Indians 7).

Golla, S. 2000. Legendary history of the TsishaDath: a working translation. Pages 133-171 in A. L. Hoover, editor. Nuu-chah-nulth voices, histories, objects \& journeys. Royal British Columbia Museum, Victoria, British Columbia, Canada.

Holling, C. S., and L. Gunderson. 2002. Resilience and adaptive cycles. Pages 25-62 in L. H. Gunderson and C. S. Holling, editors. Panarchy: understanding transformations in human and natural systems. Island Press, Washington, D. C., USA.

Hunt, G. 1898-1899. Kwakiutl texts. Microfilm; Rare Book and Manuscript Library, Columbia University Libraries, New York, New York, USA.

Johnsen, D. B. 1986. The formation and protection of property rights among the Southern Kwakiutl Indians. Journal of Legal Studies 15(1):41-67.

Johnsen, D. B. 2001. Property rights, knowledge accumulation, and salmon husbandry among Northwest Coast tribes. New York University Environmental Law Journal 10(1):1-69.

Johnson, A. W., and T. Earle. 2000. The evolution of human societies: from foraging group to agrarian state. Second edition. Stanford University Press, Stanford, California, USA.

Johnson, B. L. 1999. Introduction to the special feature: adaptive management-scientifically sound, socially challenged? Conservation Ecology 3(1): 10. [online] URL: http://www.consecol.org/vol3/iss1/art10.

Kolm, S.-C. 2000. Introduction: the economics of reciprocity, giving and altruism. Pages 1-46 in L.-A. Gerard-Varet, S.-C. Kolm, and J. Mercer Ythier, editors. The economics of reciprocity, giving and altruism. McMillan Press, London, UK.

Latour, B. 1993. We have never been modern. Harvard
University Press, Cambridge, Massachussetts, USA.

MacEvoy, A. 1998. Markets and ethics in U. S. property law. Pages 94-113 in H. M. Jacobs, editor. Who owns America? Social conflict over property rights. University of Wisconsin Press, Madison, Wisconsin, USA.

Mauss, M. 1967 [1950]. The gift: forms and functions of exchange in archaic societies. W. W. Norton, New York, New York, USA.

McIntosh, R. J., J. A. Tainter, and S. K. McIntosh, editors. 2000. The way the wind blows: climate, history, and human action. Columbia University Press, New York, New York, USA.

McNeary, S. A. 1994. Where fire came down: social and economic life of the Nisga'a. Wilp Wilxo'oskwhl Nisga'a, New Aiyansh, British Columbia, Canada.

Menninger, J. R. 2001. Research is valuable. Let's give it away. The Chronicle of Higher Education XLVIII(3):B14.

Merrill, T. W. 1998. Compensation and the interconnectedness of property. Ecology Law Quarterly 25(3):327-349.

Mills, A. 1994. Eagle down is our law: Witsuwit'en law, feasts, and land claims. UBC Press, Vancouver, British Columbia, Canada.

Mills, A., and R. Slobodin, editors. 1994. Amerindian rebirth: reincarnation belief among North American Indians and Inuit. University of Toronto Press, Toronto, Ontario, Canada.

Mitchell, D. 1990. Prehistory of the coasts of southern British Columbia and northern Washington. Pages 340-358 in W. Suttles, editor. Northwest coast. U. S. Government Printing Office, Washington, D.C. (W. C. Sturtevant, general editor, Handbook of North American Indians 7).

Newell, D. 1993. Tangled webs of history: Indians and the law in Canada's Pacific coast fisheries. University of Toronto Press, Toronto, Ontario, Canada.

Nisga'a Tribal Council. 1995a. Nisga'a clan histories. Wilp Wilxo'oskwhl Nisga'a. (Ayuukhl Nisga'a Study; II.) New Aiyansh, British Columbia, Canada.

Nisga'a Tribal Council.. 1995b. Nisga'a society. Wilp Wilxo'oskwhl Nisga'a. (Ayuukhl Nisga'a Study; IV.) New Aiyansh, British Columbia, Canada.

Nisga'a Tribal Council.. 1995c. The land and resources: traditional Nisga'a systems of land use and ownership. Wilp Wilxo'oskwhl Nisga'a. (Ayuukhl Nisga'a Study; IV.) New Aiyansh, British Columbia, Canada.

Oberg, K. 1973. The social economy of the Tlingit Indians. J. J. Douglas Ltd., Vancouver, British Columbia, Canada. 
Orans, M. 1977. Domesticating the functional dragon: an analysis of Piddocke's potlatch. American Anthropologist 77(2):312-328.

Ostrom, E. 1990. Governing the commons: the evolution of institutions for collective action. Cambridge University Press, Cambridge, UK.

Ostrom, E.. 2001. Reformulating the commons. Pages 1741 in J. Burger, E. Ostrom, R. B. Norgaard, D. Policansky, and B. D. Goldstein, editors. Protecting the commons: $a$ framework for resource management in the Americas. Island Press, Washington, D. C., USA.

Pettigrew, R. M. 1990. Prehistory of the lower Columbia and Willamette Valley. Pages 518-529 in W. Suttles, editor, Northwest coast. U. S. Government Printing Office, Washington, D.C. (W. C. Sturtevant, general editor, Handbook of North American Indians 7).

Piddocke, S. 1965. The potlatch system of the Southern Kwakiutl: a new perspective. Southwestern Journal of Anthropology 21:244-264.

Ray, A. J. 1991. The early economic history of GitksanWet'suwet'en territory. Pages 301-315 in K. Abel and J. Friesen, editors. Aboriginal resource use in Canada: historical and legal aspects. University of Manitoba Press, Winnipeg, Manitoba, Canada.

Resilience Alliance. 2002. A consortium linking ecological, economic and social insights for sustainability. [online.] URL:

http://www.resalliance.org/ev.php?URL_ID=1004\&URL_D O=DO_TOPIC\&URL_SECTION=201\&reload=104574564 9. (Accessed 20 February 2003).

Rose, A. 2000. Spirit dance at Meziadin: Chief Joseph Gosnell and the Nisga'a treaty. Harbour Publishing, Madeira Park, British Columbia, Canada.

Sax, J. L. 1964. Takings and the police power. The Yale Law Journal 74(1):36-76.

Sax, J. L. 1971. Takings, private property and public rights. The Yale Law Journal 81(2):149-186.

Schlager, E., and E. Ostrom. 1992. Property-rights regimes and natural resources. Land Economics 68(3):249262.

Seguin, M. 1984. Lest there be no salmon: symbols in traditional Tsimshian potlatch. Pages 110-133 in M. Seguin, editor. The Tsimishian: images of the past; views for the present. UBC Press, Vancouver, British Columbia, Canada.

Shein B., and D. Wheeler. 1975. Potlatch: a strict law bids us dance. T. Shandel, Producer; D. Wheeler, Director. VHS Video. Canadian Filmmakers Distribution West. Alert Bay, British Columbia, Canada.

Shindler, B., and K. A. Cheek. 1999. Integrating citizens in adaptive management: a propositional analysis. Conservation Ecology 3(1): 9. [online] URL: http://www.consecol.org/vol3/iss1/art9.

Sterritt, N. J., S. Marsden, R. Galois, P. R. Grand, and R. Overstall. 1998. Tribal boundaries in the Nass watershed. UBC Press, Vancouver, British Columbia, Canada.

Suttles, W. 1960. Affinal ties, subsistence, and prestige among the Coast Salish. American Anthropologist 62:296305 .

Suttles, W.. 1987a. Coping with abundance: subsistence on the Northwest Coast. Pages 45-63 in W. Suttles. Coast Salish essays. University of Washington Press, Seattle, Washington, USA.

Suttles, W.. 1987b. Coast Salish essays. University of Washington Press, Seattle, Washington, USA.

Suttles, W.. 1990a. Introduction. Pages 1-15 in W. Suttles, editor. Northwest coast. U. S. Government Printing Office, Washington, D. C., USA. (W. C. Sturtevant, general editor, Handbook of North American Indians 7.)

Suttles, W.. 1990b. Environment. Pages 16-29 in W. Suttles, editor. Northwest coast. U. S. Government Printing Office, Washington, D. C., USA. (W. C. Sturtevant, general editor, Handbook of North American Indians 7.)

Suttles, W., editor. 1990c. Northwest coast. U. S. Government Printing Office, Washington, D. C., USA. (W. C. Sturtevant, general editor, Handbook of North American Indians 7.)

Suttles, W.. 1991. Streams of property, armor of wealth: the traditional Kwakiutl potlatch. Pages 71-133 in A. Jonaitis, editor. Chiefly feasts: the enduring Kwakiutl potlatch. University of Washington Press, Seattle, Washington, USA.

Tainter, J. A. 1988. The collapse of complex societies. Cambridge University Press, Cambridge, UK.

Tanner, A. 1979. Bringing home the animals: religious ideology and mode of production of Mistassini Cree hunters. Hurst, London, UK.

Tanner, A.. 1988. The significance of hunting territories today. Pages 60-74 in B. A. Cox, editor. Native people, Native lands: Canadian Indian, Inuit and Metis. Carleton University Press, Ottawa, Ontario, Canada.

Trosper, R. L. 1998. Incentive systems that support sustainability: a First Nations example. Conservation Ecology 2(11). [Online.] URL: http://www.consecol.org/vol2/iss2/art11.

Trosper, R. L. 2002. Northwest coast indigenous institutions that supported resilience and sustainability. Ecological Economics 41: 329-344. 
Turner, N. J., M. B. Ignace, and R. Ignace. 2000. Traditional ecological knowledge and wisdom of Aboriginal peoples in British Columbia. Ecological Applications 10(5):1275-1287.

Varian, H. R. 1994. A solution to the problem of externalities when agents are well-informed. American Economic Review 84(5):1278-1293.

Walens, S. 1981. Feasting with cannibals: an essay on Kwakiutl cosmology. Princeton University Press, Princeton, New Jersey, USA.

Weinstein, M. S. 1994. The role of tenure and the potlatch in fisheries management by Northwest Pacific coast aboriginal societies. First Nations Fisheries Workshop. January 17-18, 1994. American Fisheries Society, Vancouver, British Columbia, Canada.

Wessen, G. 1990. Prehistory of the ocean coast of Washington. Pages 412-421 in W. Suttles, editor, Northwest coast. U. S. Government Printing Office, Washington, D. C., USA. (W. C. Sturtevant, general editor, Handbook of North American Indians 7.)

Wright, J. V. 1981. Prehistory of the Canadian shield. Pages 86-96 in J. Helm, editor. Subarctic. Smithsonian Institution, Washington, D. C., USA. (W. C. Sturtevant, general editor, Handbook of North American Indians 6.) 